\title{
UM ALVO PRIVILEGIADO
}

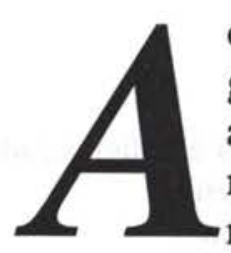

o manusear páginas, sejam as velhas conhecidas de papel que compiladas nas gráficas se nos oferecem em forma de livros, revistas, jornais, ou as que hoje, através de um simples e suave movimento de mão, velozmente deslizam ante nossos olhos na tela do computador, buscamos sempre, pacienciosa ou avidamente, a novidade, um furo de reportagem, uma temática inédita ou, para o revés desta, um novo ângulo de abordagem. Ao estamparmos a chamada "Preconceitos" nos distanciamos enormemente de qualquer ineditismo, é verdade, porém nos aproximamos de uma persistente atualidade. E talvez, mais do que isso, abrimos espaço para um mergulho nas intrincadas teias do nosso tecido social.

Duas perguntas nos alçam ao topo do trampolim. Em linguagem cru e nua: Quem é o preconceituoso? Quem é a vítima do preconceito? Muito provavelmente eu e você estejamos preparados para tecer longas considerações acerca da segunda indagação, pois somos tentados a imaginar que estamos imunes à possível pecha da primeira! Para evitar discussão particularizada, alarguemos o "eu e você" para um grande "nós", e se este for sinônimo de "brasileiros", dois textos nos instigam.

E a vítima do preconceito, quem é? A resposta parece não ser difícil - o outro! Mas há outros de todos os matizes. Interessa-nos aqui, particularmente, um outro a quem nos podemos referir como duplamente outro: o migrante. Nos casos aqui enfocados, o outrooutro é constituído por brasileiros em Portugal, kosovares e rom na Itália, latino-americanos e gringos no Brasil.

Longe, porém, a postura de um purismo ingênuo. Em última instância, por maior que seja a fragilidade do outro, este também se transforma em um nós. Por isso, no contexto imigratório, a construção das identidades coletivas explicita a constância dos preconceitos de um grupo em relação ao outro.

Uma vez envolvidos todos, quer como vítimas, quer como agentes do preconceito, não é exagero repisar que o fato de ser migrante constitui, por si só, alvo priveligiado do preconceito. Esta constatação, porém, soa cada vez mais como uma contradição, dado que o tecido social da sociedade globalizada encontra-se mais e mais amalgamado pela diversidade, pelas diferenças. Entretanto, verifica-se que, além de vítima do preconceito, o duplamente outro pode também ser transformado em objeto de manipulação frente à opinião pública, como tem ocorrido por parte da imprensa italiana em relação aos refugiados durante o conflito no Kosovo. Os que antes eram cunhados como invasores de toda estirpe, repentinamente foram transformados em coitadinhos, clamando por compaixão para, logo em seguida, voltarem a ser perigosos, um problema.

Talvez pouca novidade, mas muita atualidade - é o que nos oferecem os textos a seguir pois o preconceito grassou e grassa.

$$
\text { Dircen Cutti }
$$

